\title{
Paducah Site
}

\section{Annual Environmental Report Summary for 1994}

Project director

D. W. Frazier

Project coordinator

D. C. West

Technical coordinator

V. W. Jones

Coordinating editor

C. M. Horak

Published: February 1996

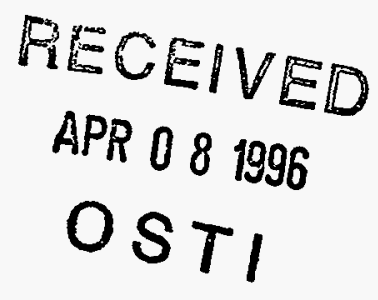

Prepared by Environmental, Safety, and Health Compliance and Environmental Management staffs, Lockheed Martin Energy Systems, Inc., P.O. Box 2008, Oak Ridge, Tennessee 37831-6285, and the Environmental Management Division, Paducah Site, Lockheed Martin Energy Systems, Inc., P.O. Box 1410, Paducah, Kentucky 42001, for the U.S. Department of Energy, under contract No. DE-AC05-84OR21400. 


\section{DISCLAIMER}

This report was prepared as an account of work sponsored by an agency of the United States Government. Neither the United States Government nor any agency thereof, nor any of their employees, make any warranty, express or implied, or assumes any legal liability or responsibility for the accuracy, completeness, or usefulness of any information, apparatus, product, or process disclosed, or represents that its use would not infringe privately owned rights. Reference herein to any specific commercial product, process, or service by trade name, trademark, manufacturer, or otherwise does not necessarily constitute or imply its endorsement, recommendation, or favoring by the United States Government or any agency thereof. The views and opinions of authors expressed herein do not necessarily state or reflect those of the United States Government or any agency thereof. 


\section{DISCLAIMIER}

Portions of this document may be illegible in electronic image products. Images are produced from the best available original document. 


\section{CONTENTS}

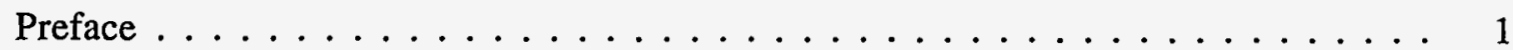

About the Paducah Site . . . . . . . . . . . . . . . . . 2

State and Federal Laws and Regulations . . . . . . . . . . . . . . 4

Restoring the Environment and Managing Waste $\ldots \ldots \ldots \ldots$

Community Participation $\ldots \ldots \ldots \ldots \ldots \ldots \ldots \ldots \ldots \ldots \ldots \ldots \ldots \ldots \ldots \ldots \ldots$

We Monitor the Environment $\ldots \ldots \ldots \ldots \ldots \ldots \ldots$

Quality Assurance and Quality Control . . . . . . . . . . . . . . . 8

We Study the Effects of Radiation and Chemicals . . . . . . . . . . . . . 9

What Do We Mean by Risk $\ldots \ldots \ldots \ldots \ldots \ldots \ldots$

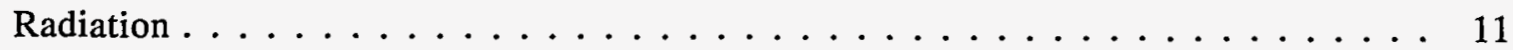

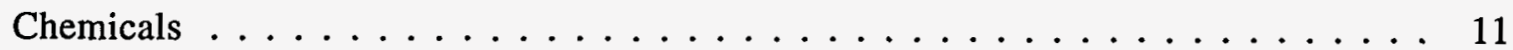

Chemical and Radiological Contaminant Pathways . . . . . . . . . . . 11

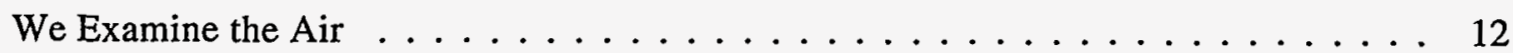

We Monitor Direct Radiation $\ldots \ldots \ldots \ldots \ldots \ldots$

We Examine Groundwater . . . . . . . . . . . . . . . . . . . 14

We Sample Soil and Sediment . . . . . . . . . . . . . . . . 16

We Monitor Deer . . . . . . . . . . . . . . . . . . 17

We Monitor Fish and Other Aquatic Life . . . . . . . . . . . . . . 17

Comparison of Dose Levels . . . . . . . . . . . . . . . . . . 18

So . . What Does It All Mean? . . . . . . . . . . . . . . . . . . . 20 


\section{PREFACE}

This pamphlet contains summaries of the environmental programs at the Paducah Gaseous Diffusion Plant site, environmental monitoring and the results, and the impact of operations on the environment and the public for 1994. More detailed information on the material summarized in this pamphlet is available in the Paducah Site Annual Environmental Report for 1994. The data used to compile the site annual environmental report and this summary are published in the Paducah Site Annual Environmental Data for 1994, which is a collection of tables containing effluent monitoring, environmental surveillance, and dose calculation data for 1994.

To obtain copies of any of these documents, contact

Vicki W. Jones

Environmental compliance coordinator

Paducah site

761 Veterans Avenue

Kevil, KY 42053

Telephone: 502-441-5058 


\section{ABOUT THE PADUCAH SITE}

The Paducah Gaseous Diffusion Plant (PGDP) site is one of two government-owned, contractor-operated uranium enrichment facilities within the U.S. Department of Energy (DOE) complex (Figure 1). As of July 1, 1993, responsibility for environmental compliance was split between DOE, as site owner and operator of waste management and environmental remediation projects, and the United States Enrichment Corporation (USEC), a government-owned corporation formed by the National Energy Policy Act of 1992 to take over the nation's uranium enrichment business. Lockheed Martin Energy Systems (Energy Systems), formerly Martin Marietta Energy Systems, manages and operates the Paducah site for DOE. Lockheed Martin Utility Services (formerly Martin Marietta Utility Services) provides operating and maintenance services for USEC. The Nuclear Regulatory Commission is scheduled to assume direct oversight of USEC operations in October 1995. Until then, DOE is providing oversight of nuclear safety and safeguards and security.

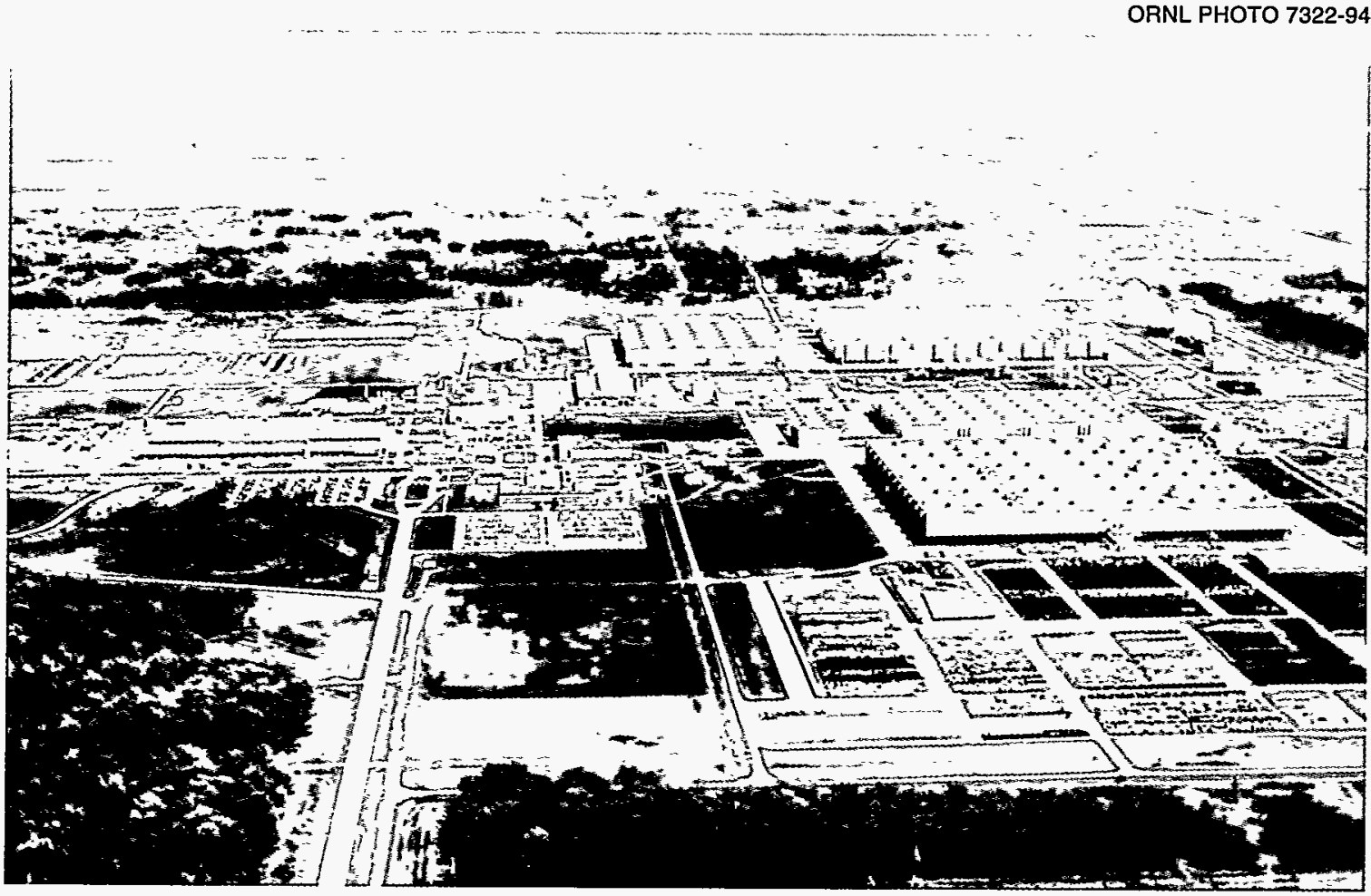

Figure 1. Paducah Gaseous Diffusion Plant is one of two DOE-owned uranium enrichment facilities. The other facility is in Portsmouth, Ohio. (Photo courtesy of Energy Systems Public Affairs, Kevil, Kentucky.)

The Paducah facility is located in McCracken County, Kentucky, about 10 miles west of the city of Paducah and 3 miles south of the Ohio River. About 750 acres are contained within the security fence, where the buildings containing uranium enrichment process equipment and support facilities are located (Figure 2). The population within 50 miles of the plant site is about 300,500 .

Before World War II, the area now occupied by the Paducah site was used for agricultural purposes. Numerous small farms produced various grain crops and provided pasture for livestock. Early in the war, a 16,126-acre tract was assembled for construction 


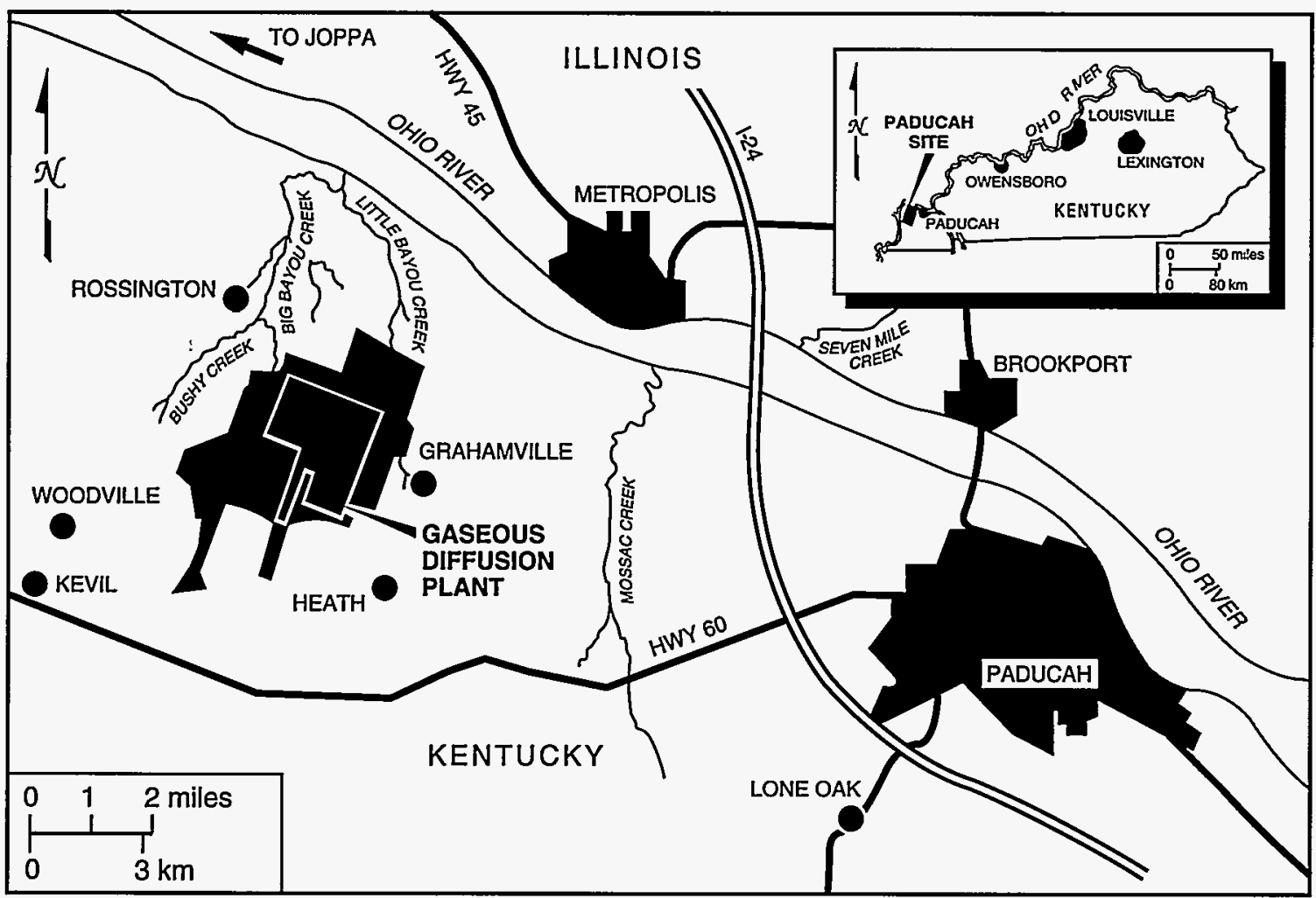

Figure 2. Location of the Paducah site within the state of Kentucky and in relation to the geographic region.

of the Kentucky Ordnance Works, which was subsequently operated by the Atlas Powder Company until the end of the war when it was turned over to the Federal Farm Mortgage Corporation and then to the General Services Administration.

In 1950, the Department of Defense and DOE's predecessor, the Atomic Energy Commission (AEC), began efforts to expand fissionable material production capacity. As part of this effort, the National Security Resources Board was instructed to designate power areas within the strategically safe area of the United States. Eight government-owned sites were initially selected as candidate areas, one of which was the Kentucky Ordnance Works site. In October 1950, as a result of joint recommendations from the Department of Defense, Department of State, and the AEC, President Truman directed the AEC to further expand production of atomic weapons. One part of this expansion program was the provision for a new gaseous diffusion plant. In October 1950, the AEC approved the Paducah site for uranium enrichment operations and formally requested the Department of the Army to transfer the site from the General Services Administration to the AEC.

Construction of the Paducah plant was completed in 1954, although production began in 1952. The plant's mission, uranium enrichment, has continued unchanged, and the original facilities (with substantial upgrading and refurbishment) are still in operation. Of the 7566 acres acquired by the AEC, 1361 were subsequently transferred to the Tennessee Valley Authority (Shawnee Steam Plant site), and 2781 acres were conveyed to the commonwealth of Kentucky for use in wildlife conservation and recreational purposes. Thus, the site now occupies 3424 acres. 


\section{STATE AND FEDERAL LAWS AND REGULATIONS}

The philosophy of environmental compliance at the Paducah site is to protect employee and public health and the environment while complying fully with all environmental rules and regulations. Growth in public awareness and environmental concern in recent years has prompted Congress to pass increasingly stringent laws to protect the environment. In keeping with our philosophy, we continue to work closely with the regulating agencies to minimize the effect of plant operations and historic activities on public health and the environment and to ensure continued compliance with regulations.

The U.S. Environmental Protection Agency (EPA) and the Kentucky Department for Environmental Protection are the principal regulatory agencies. These agencies issue permits, review compliance reports, participate in joint monitoring programs, inspect facilities and operations, and oversee compliance with applicable regulations. To continue operations, the Paducah site must comply with numerous federal and state laws, a few of which follow.

- Clean Air Act

- Clean Water Act

- Comprehensive Environmental Response, Compensation, and Liability Act

- DOE/Kentucky Agreement in Principle

- Emergency Planning and Community Right-To-Know Act

- Endangered Species Act (see Figure 3)

- Farmland Protection Act

- Federal Facilities Compliance Act

- Federal Insecticide, Fungicide, and Rodenticide Act

- National Environmental Policy Act

- National Historic Preservation Act

- Resource Conservation and Recovery Act

- Safe Drinking Water Act

- Toxic Substances Control Act

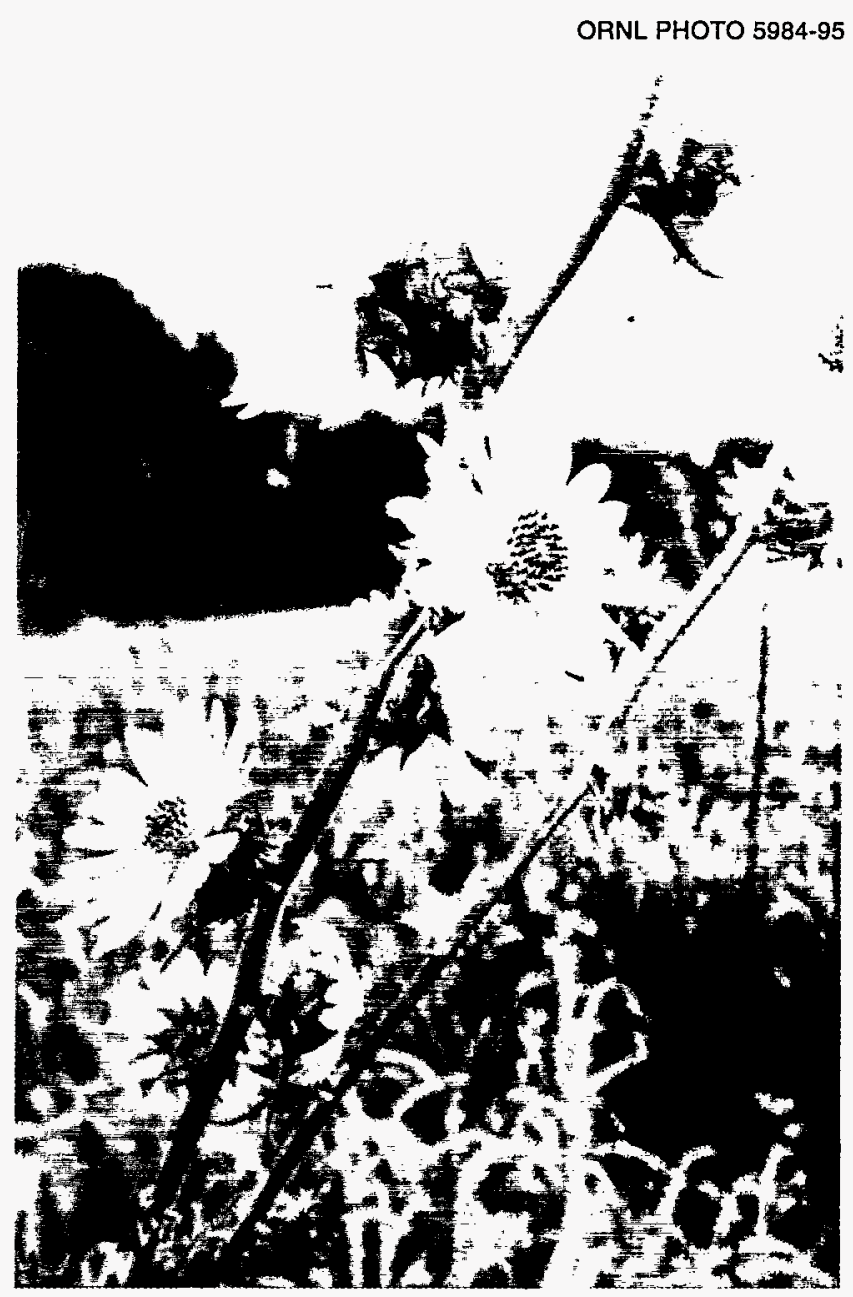

Figure 3. The western Kentucky area provides an ideal habitat for several plants of interest, for example, the compass plant (SIIphium laciniatum). Ploneers gave the plant this name because of the north-south orientation of the leaves. (Photo courtesy of Energy Systems Public Affairs, Kevil, Kentucky.) 


\section{RESTORING THE ENVIRONMENT AND MANAGING WASTE}

Environmental restoration and waste management activities are carried out to protect the local population, improve the quality of the environment, and comply with federal and state regulations.

- Environmental restoration is the cleanup of wastes in the environment that originated from activities on the reservation.

- Waste management is the control of wastes, including their destruction or permanent storage.

\section{Environmental Restoration}

Environmental restoration is the process of cleaning up inactive waste sites and facilities to ensure that risks to human health and the environment are either eliminated or reduced to safe levels. This task may be accomplished by removing, stabilizing, or treating hazardous substances. The federal law that addresses the restoration of inactive waste sites is the Comprehensive Environmental Response, Compensation, and Liability Act. This legislation includes identification of waste sites with the most urgent need for cleanup because of an increased risk to public health or the environment. These sites are put on the EPA's National Priorities List. On May 31, 1994, the Paducah site was added to this list. Consequently, the site is in the process of finalizing a federal facilities agreement with the appropriate regulatory agencies. This agreement will serve as a comprehensive procedure for remediation of the site and requires the site to submit a plan that outlines remediation priorities and presents schedules for completing the work.

\section{Waste Management}

Gaseous diffusion operations generate hazardous and mixed wastes (waste containing both radioactive and hazardous chemical components). The Paducah site is permitted to treat and temporarily store certain materials on site. These wastes are accumulated on site until they can be shipped off site for permanent treatment, storage, or disposal at authorized sites.

The Paducah site, as well as all other DOE facilities, prepared a draft site treatment plan that includes the study of options for treatment of mixed wastes that are preferred both environmentally and economically. This plan was submitted to regulators for final approval in March 1995.

Public participation in the early stages of decision making can help identify issues and focus planning efforts. Community awareness and involvement are vital to DOE's success. Federal law requires public comment on proposed cleanup plans, and such public input has a direct bearing on the decisions made.

\section{Waste Minimization/Pollution Prevention Program}

The Waste Minimization/Pollution Prevention Program provides guidance and objectives for minimizing solid waste generation and discharges to the environment. Conserving natural resources and protecting the environment is DOE policy. 


\section{COMMUNITY PARTICIPATION}

The Paducah site has a comprehensive community relations and public participation program regarding DOE activities at the site. The purpose of the program is to conduct a proactive public involvement program, with outreach components, to foster a spirit of openness and credibility among local citizens and various segments of the public. The program is also geared to provide the public with opportunities to become involved in the decisions affecting environmental issues at the site.

\section{Public Affairs Programs}

\section{Information Bulletins, Fact Sheets, and Public Briefings}

During 1994, the site published a general information bulletin on environmental issues and cleanup activities for DOE operations. The bulletin was distributed to about 4000 recipients throughout the region. Fact sheets on several topics, including updates on the federal facilities agreement and the Federal Facilities Compliance Act, were also published and distributed.

A public workshop on a variety of environmental restoration and waste management projects was conducted in June 1994. Included were information tables on the proposed landfill and a draft site treatment plan for mixed waste. State and federal regulators also set up information tables and discussed projects and regulatory issues with attendees. In December, a public meeting was conducted to discuss the Depleted Uranium Hexafluoride Cylinder Program and a related programmatic environmental impact statement being prepared by DOE Headquarters, along with other issues of interest to the public (see Figure 4). DOE also conducted an availability session on the proposed landfill, during which members of the public could speak directly to DOE and contractor personnel about the project.

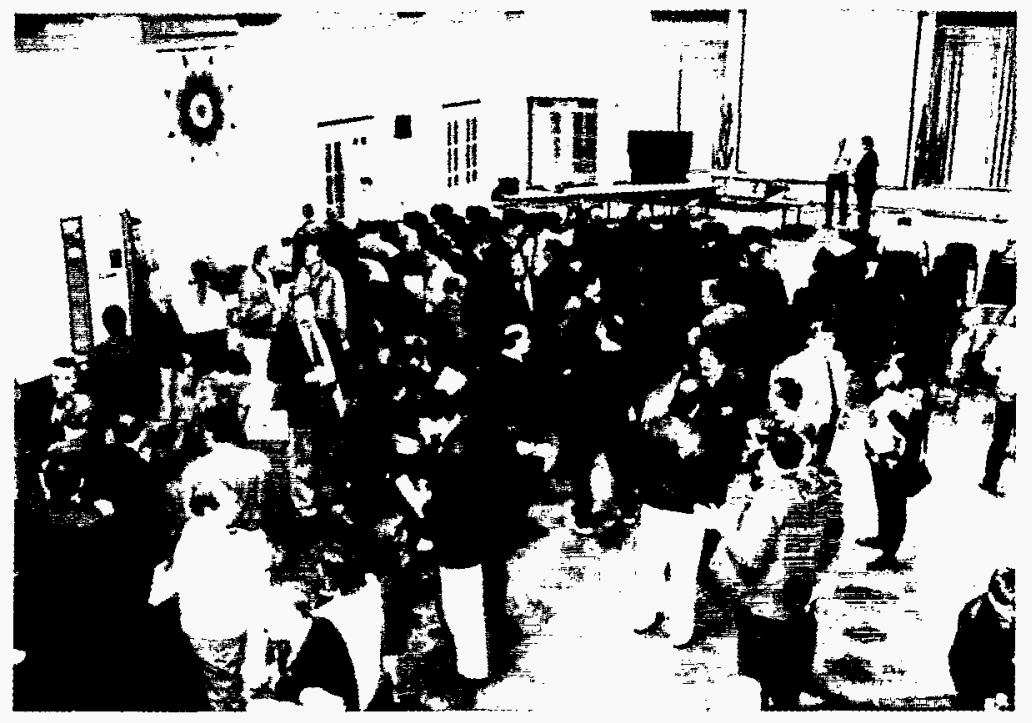

Figure 4. Public meeting held in December 1994 regarding DOE issues. (Photo courtesy of Energy Systems Public Affairs, Kevil, Kentucky.)

\section{Environmental Advisory Committee}

The Paducah Environmental Advisory Committee was chartered in 1986 as part of a program to solicit input from experts and the general public on environmental issues at Energy Systems facilities. The committee is made up of scientists, academics, business 
people, and members of the general public. The committee is currently composed of five members who meet quarterly to be briefed on a wide range of issues and to provide meaningful input on several projects.

\section{Earth Day}

Personnel from the Paducah site, Heath Middle School, and the West Kentucky Wildlife Management Area joined together to plan and implement the 1994 Earth Day activities. A wide variety of environmental educational programs were available, using both the Wildlife Management Area and DOE property. Paducah employees supported the event by supervising an Environmental Restoration Earth Renewal Challenge Maze. Students were challenged to work through a restoration project including managing funding, meeting schedules, and working with regulators. Paducah employees also conducted a demonstration on how groundwater wells are constructed and how samples are taken (see Figure 5). Students were also given an opportunity to see DOE's working landfill and to listen to an overview of the regulations that govern proper use of the facility (see Figure 6).

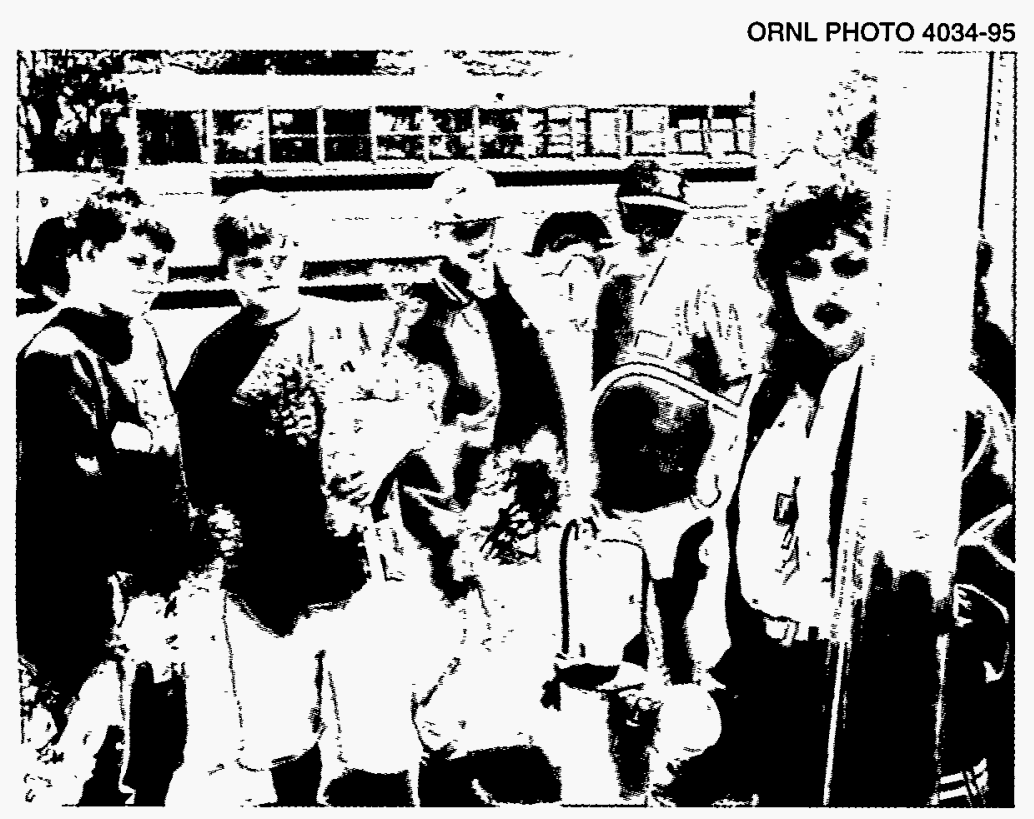

Figure 5. A Paducah site employee demonstrates the construction and use of a groundwater well. (Photo courtesy of Energy Systems Public Affairs, Kevil, Kentucky.)

Figure 6. Heath Middle School students participating in 1994 Earth Day activities. (Photo courtesy of Energy Systems Public Affairs, Kevil, Kentucky.)

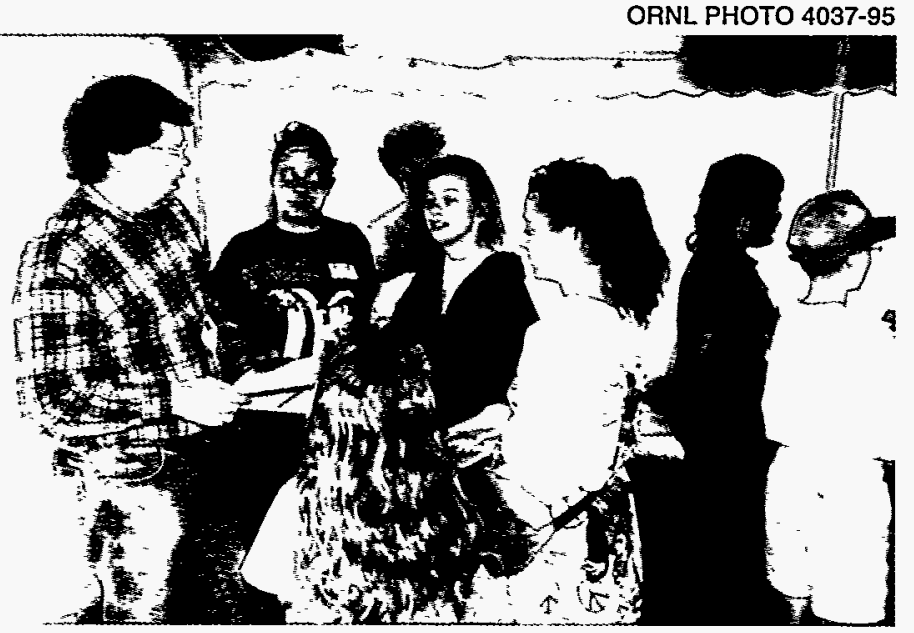




\section{WE MONITOR THE ENVIRONMENT}

The environmental monitoring program at the Paducah site has two components-effluent monitoring and environmental surveillance, both of which are intended to demonstrate that reservation operations comply with DOE criteria as well as other applicable federal, state, and local standards and requirements.

- Effluent monitoring is sampling known air and water discharge points to determine the amount of radioactive and chemical contaminants (if any) contained in the released material.

- Environmental surveillance is sampling air, water, soil, and wildlife to detect any radioactive or chemical contaminants that could have come from DOE activities.

Information from monitoring and surveillance is also used to document compliance with appropriate standards, identify trends, inform the public, and contribute to general environmental knowledge.

We monitor the local environment to acquire data so that we can reduce and, where practical, eliminate the release of radioactive and nonradioactive environmental pollutants. Information gathered during specific monitoring programs is published in routine reports to local, state, and federal agencies and to the public. The environmental monitoring program assists in fulfilling DOE's policy of protecting the public, employees, and the environment from harm that could be caused by its activities and in reducing negative effects on the environment to the greatest degree practical.

\section{QUALITY ASSURANCE AND QUALITY CONTROL}

When monitoring releases and measuring radiation in the environment, the reliability of the data is of the utmost importance. To ensure that the monitoring and measurement results are accurate, the Paducah site has a quality assurance and quality control program based on guidelines from the EPA, the American Society for Testing and Materials, and other federal and state agencies. The Environmental Department at the Paducah site administers internal quality control programs to ensure reliability of the data on a day-to-day basis (see Figure 7).

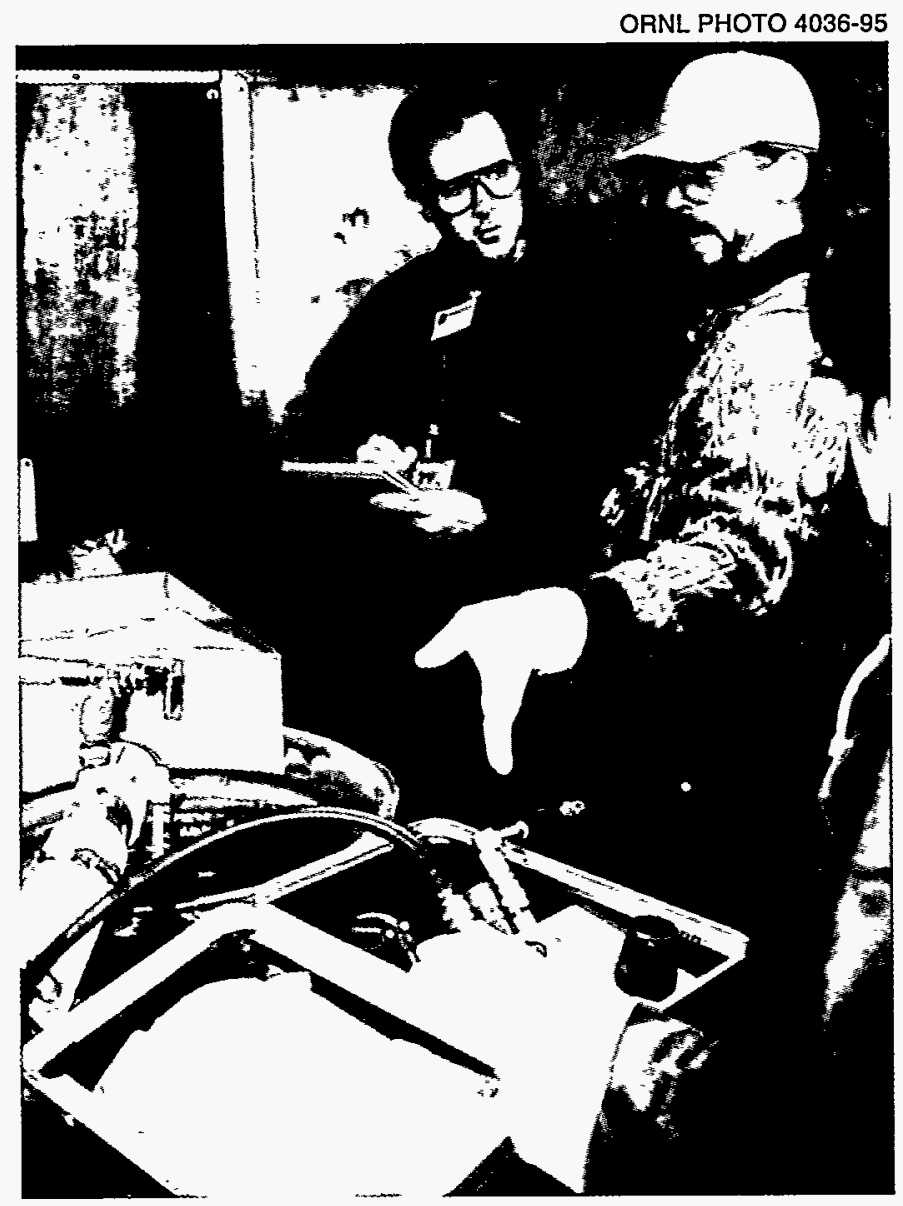

Figure 7. Regulators from DOE and the EPA regularly audit monitoring activities at the Paducah site to ensure that established procedures are followed properly. (Photo courtesy of Energy Systems Public Affairs, Kevil, Kentucky.) 


\section{WE STUDY THE EFFECTS OF RADIATION AND CHEMICALS}

Activities at the Paducah site involve handling radioactive materials and working with chemicals known to be harmful to humans and the environment. Radiological and chemical "dose" assessments evaluate the possible exposure of the public to radioactive elements and harmful chemicals from the site. We assess and record compliance with regulations for protection of employees, the public, and the environment (see Figure 8).

The most important potential source of exposure to radiation from the Paducah site is direct external radiation from and ingestion of sediment in or near the Little Bayou Creek bed. The most important potential source of exposure to harmful chemicals is polychlorinated biphenyls (PCBs) in liquid effluents and fish.

Thousands of samples of air, soil, and water are analyzed each year. The results are used to determine the amount of exposure that a hypothetical, "maximally exposed" individual could receive in a year as a result of DOE operations at the site.

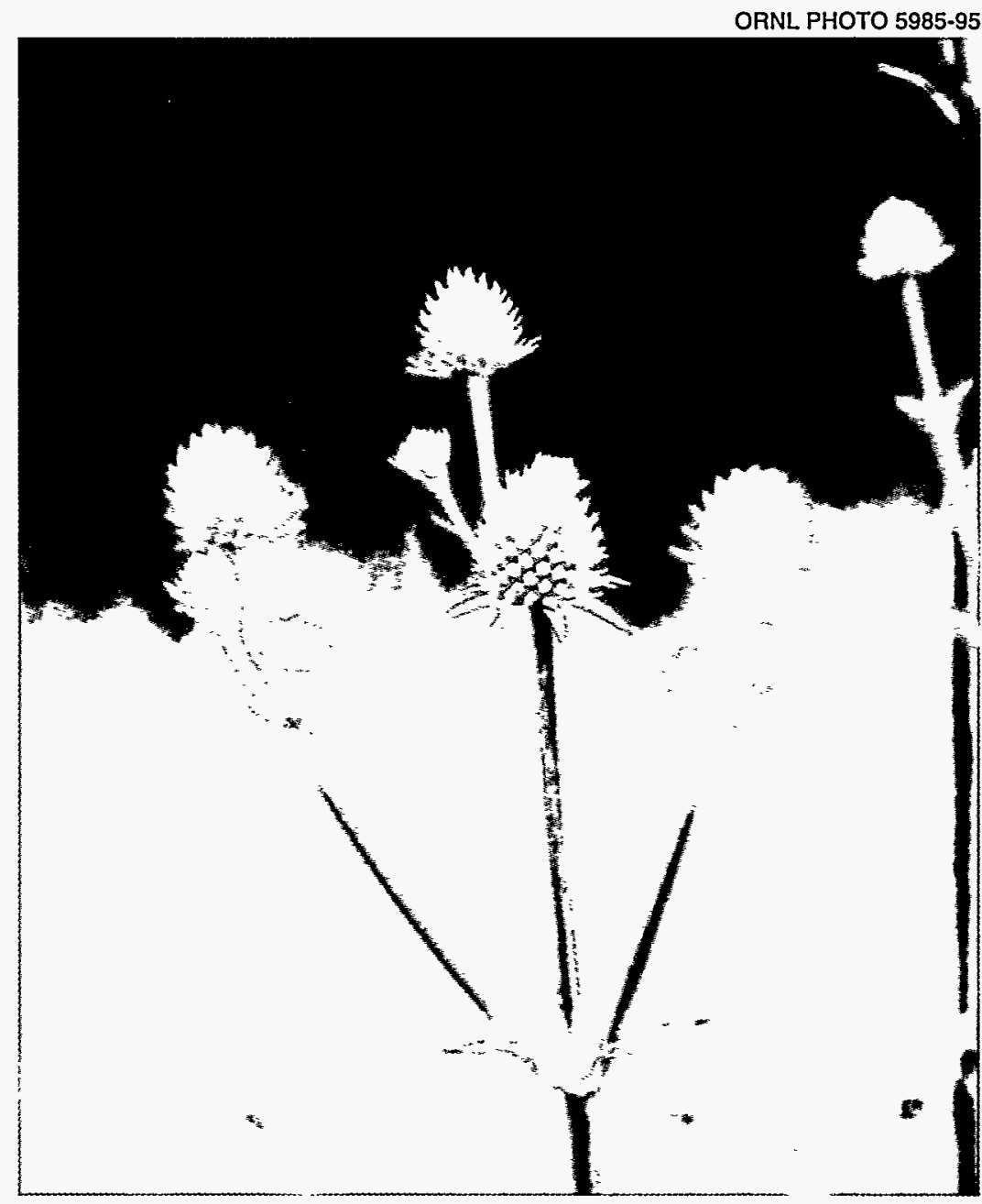

Figure 8. The rattlesnake master plant (Eryngium yuccifolium) is found in only three areas of Kentucky, one of which is in western Kentucky. Although the plant itself is not threatened or endangered, it is considered to be very important because the rattlesnake master bore moth depends on the plant for its survivial. (Photo courtesy of Energy Systems Public Affairs, Kevil, Kentucky.) 


\section{WHAT DO WE MEAN BY RISK?}

When we estimate the risk associated with activities on the DOE reservation and the West Kentucky Wildlife Management Area, we are calculating the odds of activities on the reservation affecting the health of the local population. These calculations are based on known effects that specific chemicals and radiation have on the human body. All of the sampling and analysis compiled in the Paducah site annual environmental report culminate in the calculation of "dose" of radiation and chemicals to the public (if any) that can be attributed to DOE and USEC activities on the site.

The calculated maximum effective dose equivalent for radiation in 1994 was 3.03 mrem. This calculation is based on a hypothetical adult who would have received the maximum exposure from all reservation sources during the year. This amount is about $1 \%$ of the dose that an individual receives from natural local background radiation sources, which averages 300 mrem per year. Figure 9 shows how the potential dose of 3.03 mrem per year compares with the DOE limit and the average dose from background radiation to residents in the Paducah area.

Paducah uses the concept of the maximally exposed individual when estimating its contribution to the dose to the off-site population to ensure that the estimate is the highest any one individual could have received as a result of DOE and USEC operations. In reality, however, no individual actually receives this high a dose from operations at the site.

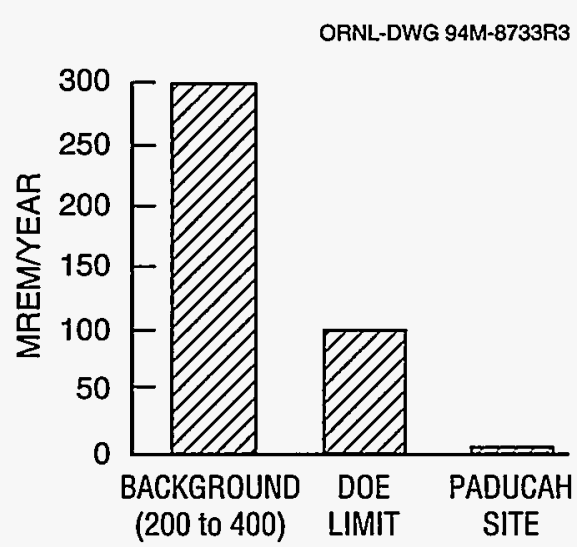

Figure 9. Comparison of combined dose from all exposure pathways from the Paducah site to background dose and the DOE limit. 


\section{RADIATION}

Radioactive material contains unstable atoms (isotopes) that become stable by emitting electromagnetic radiation and high-energy particles. All naturally occurring and human-made isotopes are identical with regard to the particles and energy they emit.

- Dose is an estimate of the amount of energy absorbed per unit of mass (in units of rads or grays or submultiples thereof).

- Dose equivalent is a measure of the amount of effective radiation absorbed (in units of rem or sieverts or submultiples thereof) when modifying factors such as the type of radiation and its distribution are considered. It places all types of radiation on the same biologically equivalent scale.

- Effective dose equivalent relates the dose equivalents to the risk to the whole body.

- Committed effective dose equivalent is the total internal dose equivalent received over a 50 -year period from intake of radionuclides in 1 year.

\section{CHEMICALS}

- Chemical dose is the estimate of the amount of a chemical to which a human body is exposed daily.

- Toxicity refers to the adverse effects, ranging from mild irritation to death, that a chemical can have on human health. Dose estimates are compared with EPA standards to benchmark their level of toxicity.

\section{CHEMICAL AND}

\section{RADIOLOGICAL} CONTAMINANT PATHWAYS

We can receive internal or external exposure to chemicals and radioactive materials by a number of pathways: direct, airborne, waterborne, and the food chain. We receive radiation directly from cosmic radiation and from particles embedded in soil and suspended in air and water. We can breathe air or drink water that has both chemical and radiological airborne contaminants suspended in it. Airborne contaminants that settle on grass in a pasture can be eaten by cows, and the contaminants could show up in the milk we drink. Likewise, contaminants in water can be ingested and retained by fish we eat (see Figure 10).

At the Paducah site, essentially all of the radiation dose to the public is from radioactive forms of two elements: uranium and technetium. Of the two,

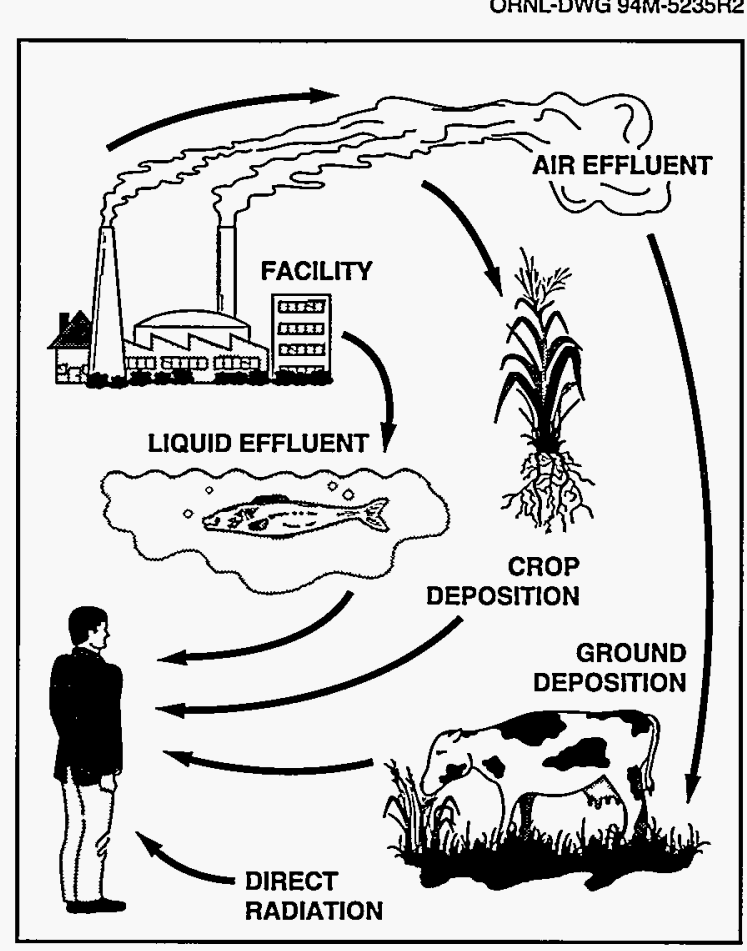

Figure 10. Possible pathways for radiation and chemicals to reach humans. 
1 curie of uranium $(3000 \mathrm{~kg}$ ) will cause committed dose equivalents 174 times greater than 1 curie of technetium (59 g) if swallowed and $1.42 \times 10^{4}$ times greater if inhaled.

\section{WE EXAMINE THE AIR}

- Ambient air is the air that exists in the environment.

- Effluent air flows from a source out into the environment.

Air monitoring programs provide information to protect the health of plant workers and the general public and to demonstrate compliance with state and federal air quality requirements. Programs are upgraded through the years to meet revisions in state and federal requirements.

Both radiological and nonradiological air emissions from individual buildings and specific plant locations and in the surrounding communities are monitored (see Figure 11). Figure 12 shows the meteorological tower at the Paducah site where air monitoring data is gathered. Airborne emissions were monitored for five radionuclides, and all were within acceptable limits set by DOE and federal and state standards. The average concentrations of radionuclides at all monitoring locations were small percentages (ranging from 1 to $16 \%$ ) of the allowable limits set by DOE. Measurements of radioactivity in the air on and around the Paducah reservation were well within applicable standards and were not significantly affected by Paducah releases.

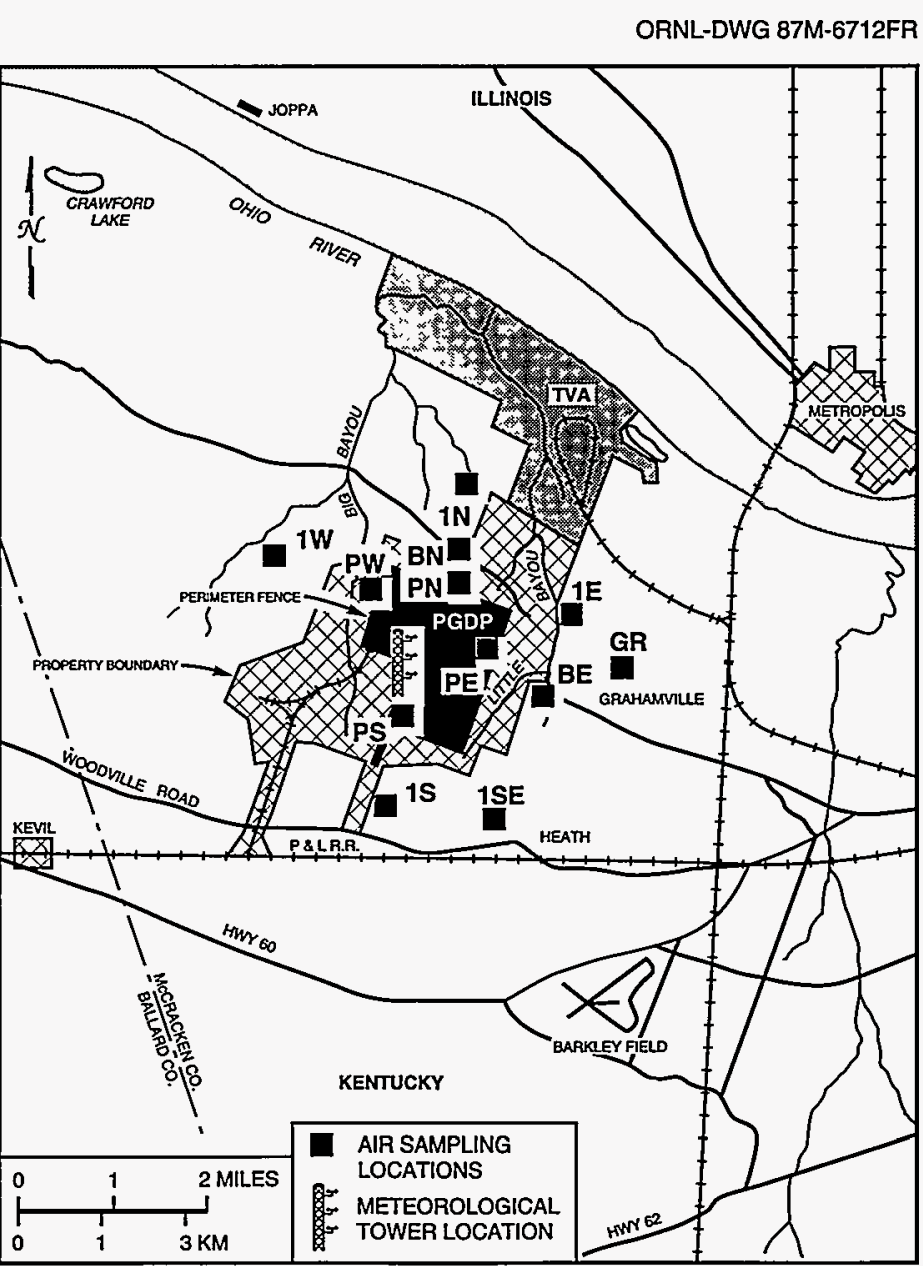

Figure 11. Air sampling and meteorological monitoring stations at and near the Paducah site.

Nonradiological emissions of concern include potentially harmful chemicals and pollutants. Emissions in 1994 were all within applicable limits. 


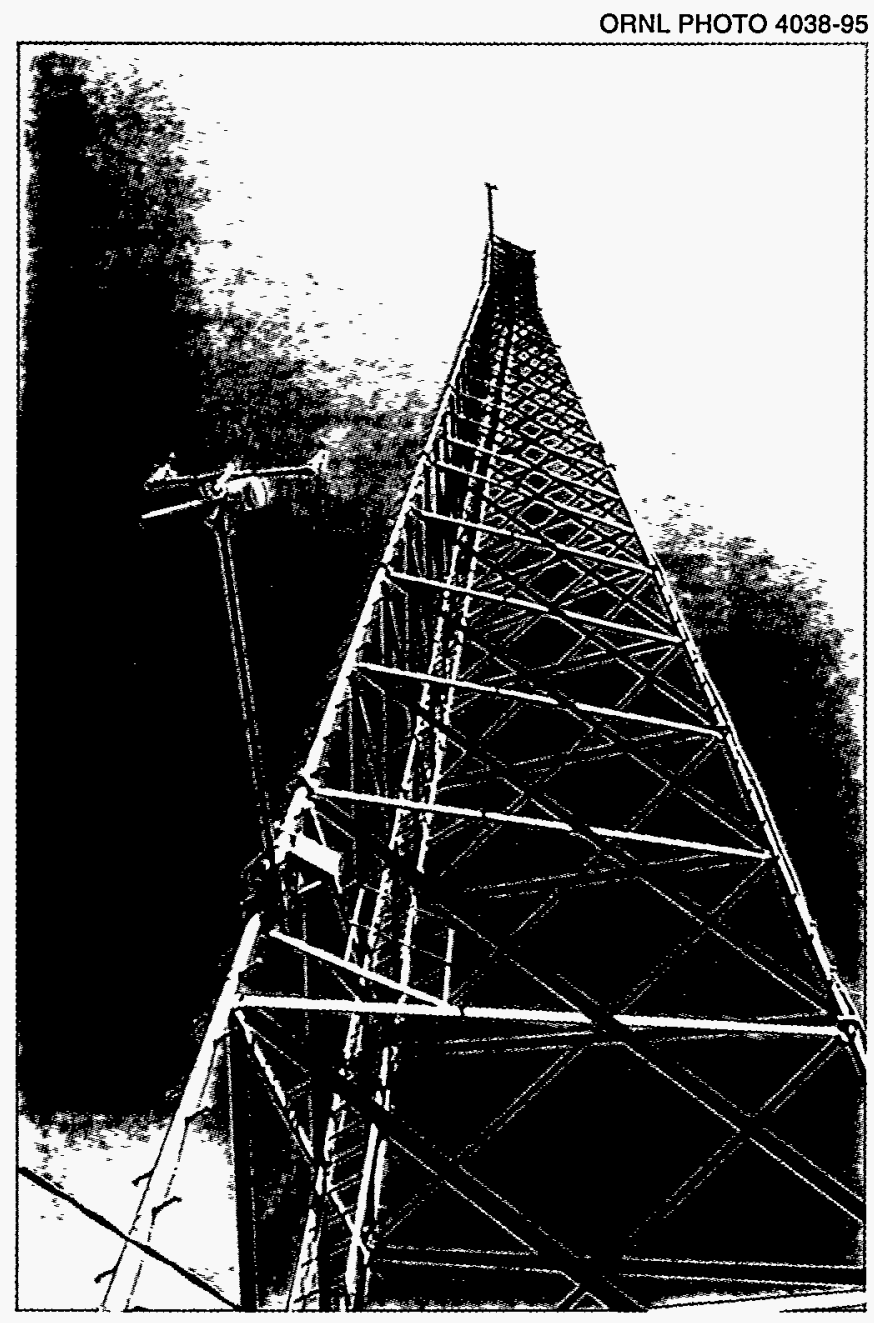

Figure 12. A meteorological tower is used to monitor wind direction and speed. This information is used to calculate the dispersion of radioactive particles and chemicals through the air.

\section{WE MONITOR DIRECT RADIATION}

To determine a realistic exposure time for the Little Bayou Creek area, several assumptions were used. During 1994, the West Kentucky Wildlife Management Area allowed hunting and dog trials in this area from January 1 to March 31 and from September 1 to December 31 (213 days). For exposure in the creeks, an individual was assumed to hunt every other day during this period and spend 30 minutes in the Little Bayou Creek bed. This exposure time is probably exaggerated because most areas are fenced and signs are posted in this area stating that prolonged exposure could result in a dose above background. Also, observations indicate that hunters spend very little time in creeks near the plant. Using the maximum exposure rate measured in the Kentucky Pollutant Discharge Elimination System 011 ditch (which is fenced and posted before discharging into Little Bayou Creek) as the worst-case estimate for Little Bayou Creek, the dose above background to this maximally exposed individual would be $1 \mathrm{mrem} / \mathrm{year}$. Even using these extreme assumptions, the potential dose is within the guideline value of less than $10 \mathrm{mrem} / \mathrm{year}$ from any one pathway. 


\section{WE EXAMINE GROUNDWATER}

By sampling the groundwater, we are able to evaluate the impact of DOE activities on local groundwater and to limit any activities that have an adverse effect on the groundwater. Major federal regulations specify actions to be followed in the groundwater monitoring program. Sampling is conducted at over 200 monitoring wells, residential wells, and wells that belong to the Tennessee Valley Authority (see Figure 13).

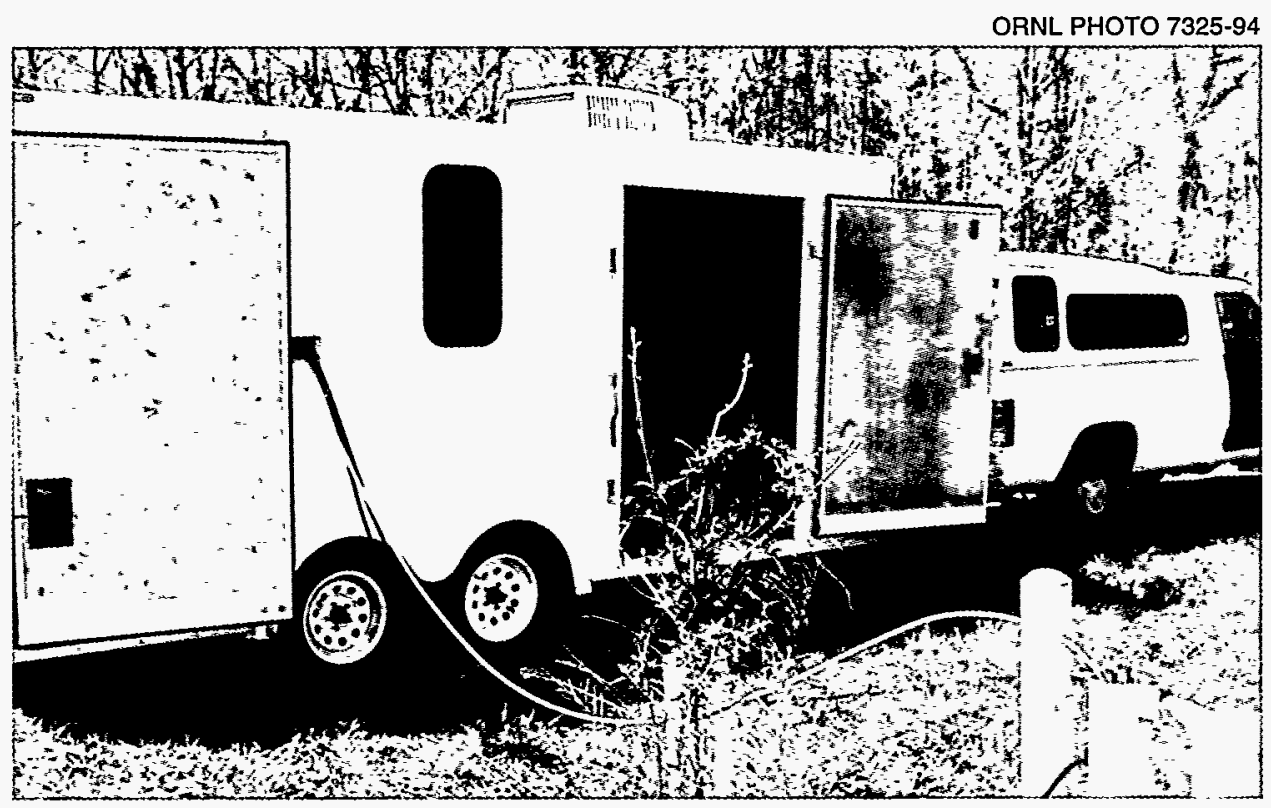

Figure 13. Mobile laboratory used to conduct groundwater well sampling.

Radiological groundwater monitoring is conducted for specific radionuclides as well as general levels of radioactivity. Technetium-99 $\left({ }^{99} \mathrm{Tc}\right)$ is the only major threat to the regional gravel aquifer, a local groundwater area that provides drinking water to area residents. Areas contaminated with ${ }^{99} \mathrm{Tc}$ are shown in Figure 14.

Nonradiological groundwater monitoring focuses primarily on trichloroethylene (TCE), a degreasing agent used by many industries until its harmful environmental effects were discovered. TCE is a dense nonaqueous phase liquid (DNAPL), that is, a liquid with a density greater than water. DNAPLs are extremely difficult to remove. In fact, because technology does not yet exist to remove them from aquifers, DNAPLs are a continuing source of groundwater contamination. Although other chemicals are monitored, TCE appears to be the only nonradiological contaminant threatening the regional gravel aquifer. TCE-contaminated areas are identified on Figure 14.

In July 1988, the Paducah site began providing bottled water to residents with affected wells. Since then, DOE has established a water policy that includes extending a municipal water line to the entire area that could be affected by groundwater contamination originating from the Paducah site. All residents within the area, regardless of whether or not their wells were contaminated, were given the opportunity to receive municipal water at DOE expense when signing an agreement not to use or dig wells on their property. Installation of the water line was completed in 1994. 
ORNL-DWG 95M-8127

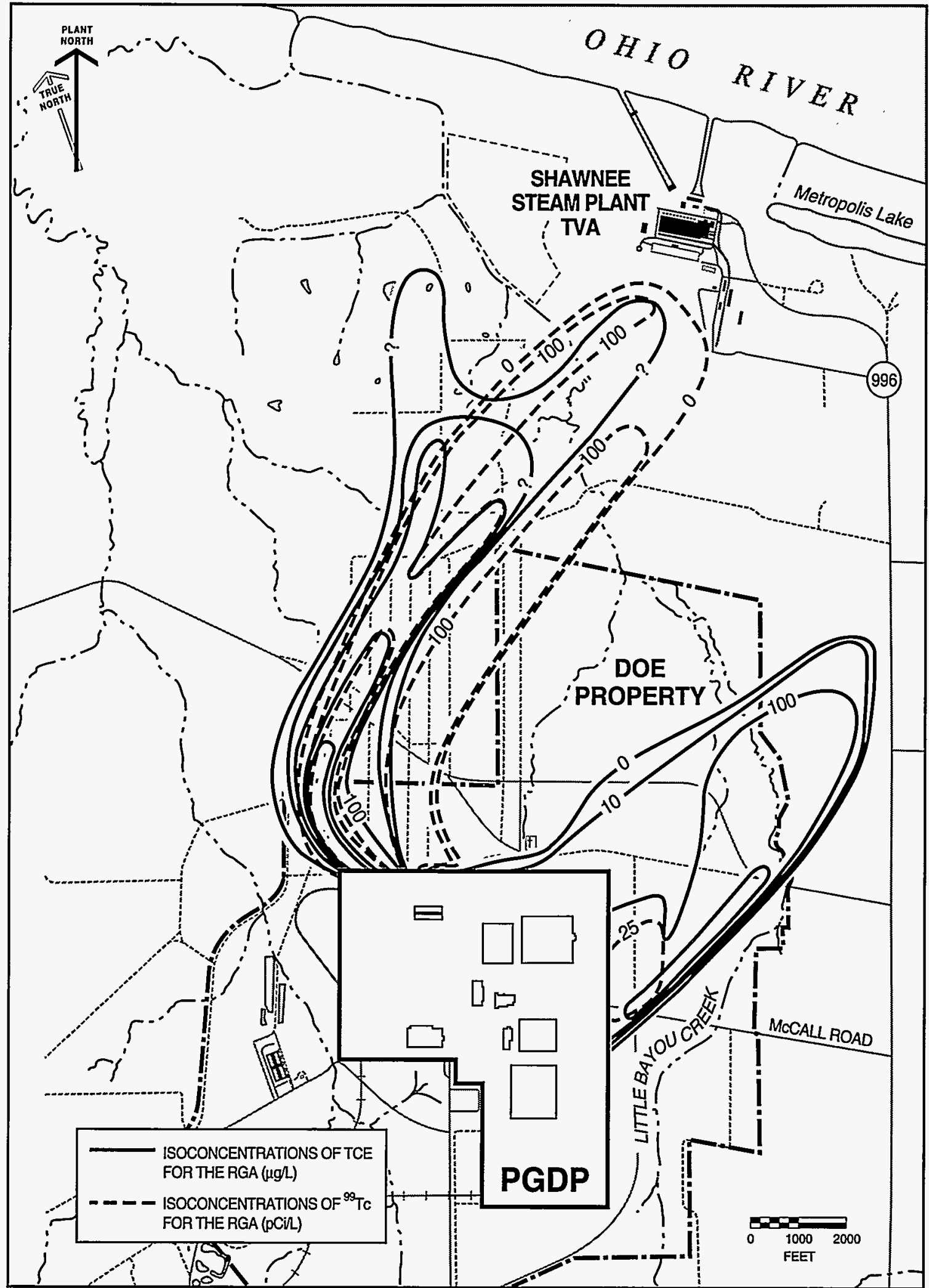

Figure 14. TCE and ${ }^{99} \mathrm{TC}$ groundwater plumes on and near the Paducah site. 


\section{WE SAMPLE SOIL AND SEDIMENT}

\section{Soil}

Soil is sampled to determine if radionuclides from the atmosphere are accumulating in the soil. Soil samples are taken annually at ten locations at the property boundary and at distances of 5 miles beyond the property boundary (see Figure 15). Remote samples are taken at two locations 8 to 9 miles from the plant. Although other radiochemical analyses are performed, the results for uranium are considered the most important because uranium is the element of greatest concern in plant air emissions. The 1994 uranium concentrations show no apparent differences from past data and are within the range for concentrations and assay expected for naturally occurring uranium.

\section{Sediment}

The stream bottom is an important constituent of the aquatic environment. If a pollutant is a suspended solid or is attached to suspended sediment, it can settle to the bottom (thus creating the need for sediment sampling), be filtered by certain organisms, or become attached to plant surfaces. Sediment samples are taken from six locations (see Figure 15). Uranium and PCB levels were higher in downstream Little Bayou Creek than at upstream Little Bayou Creek. In addition, uranium levels at SS1, downstream Big Bayou Creek, were ten times higher than at SS20, upstream Big Bayou Creek, and slightly higher than 1993 levels. These elevated levels can be attributed to plant operations (such as runoff for contaminated scrap yards) because the assay is lower than natural uranium. The monitoring program confirms past studies in which uranium and PCBs had been detected and resulted in the posting of Little Bayou Creek to make the public aware of PCB contamination and that prolonged exposure could result in a dose above background.
ORNL-DWG 87M-6712BR4

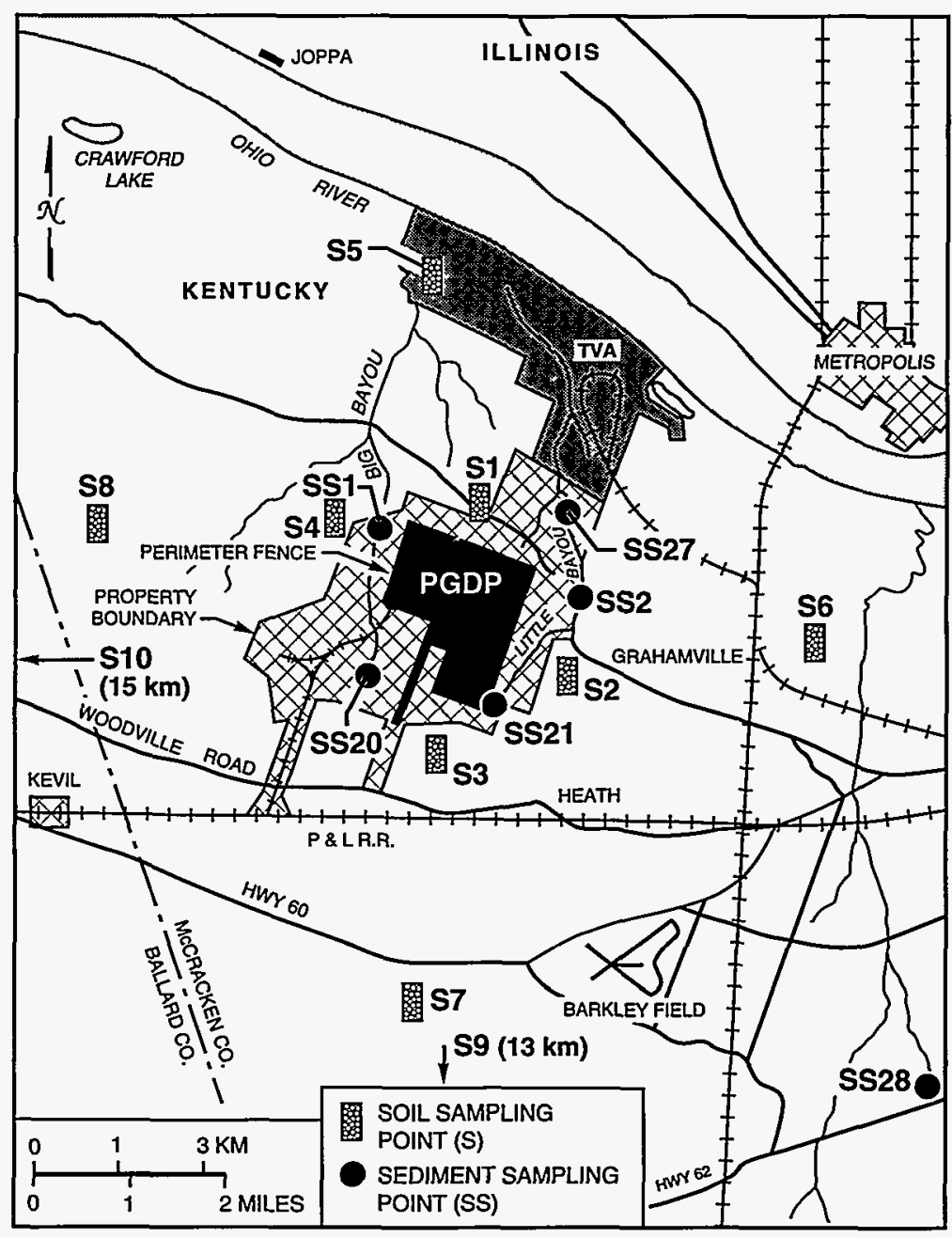

Figure 15. Soil and sediment sampling locations at the Paducah site. 


\section{WE MONITOR DEER}

The data from radiological sampling indicated no significant difference between the average concentrations of uranium isotopes in liver or muscle for reservation deer and for background deer taken from the Ballard County Wildlife Management Area. Very small concentrations of plutonium-239 and ${ }^{99} \mathrm{Tc}$ were found in muscle tissue of reservation deer. If one person ate all of both deer found with measurable levels of both radionuclides, he or she would receive a dose of 1.67 mrem.

\section{WE MONITOR FISH AND OTHER AQUATIC LIFE}

Energy Systems sponsors a biological monitoring program that is conducted each year by Oak Ridge National Laboratory. The program consists of three major tasks: (1) effluent and ambient toxicity monitoring, (2) bioaccumulation monitoring, and (3) ecological monitoring of stream communities.

\section{Toxicity Monitoring}

Ceriodaphnia and fathead minnow toxicity tests of effluents are conducted quarterly. For ambient tests conducted in 1994 , there was no evidence of chronic toxicity to fathead minnows for any of the ambient sites. Thus, toxicity to minnows observed in effluent from the continuously flowing outfalls was not observed in instream samples following mixing zones.

\section{Bioaccumulation Monitoring}

The objectives of the bioaccumulation monitoring were to (1) continue PCB tracking studies in fish from Big Bayou Creek and Little Bayou Creek and (2) conduct screening analyses to detect other contaminants that may be of concern to consumers of fish from these streams. Overall mean concentrations of PCBs immediately downstream of DOE outfalls exceeded concentrations from the reference sites. Concentrations of metals were similar to reference streams, and no chlorinated pesticides were detected in fish from Big Bayou Creek or Little Bayou Creek. Detectable concentrations of uranium were found in fish from Little Bayou Creek.

\section{Ecological Monitoring}

Quantitative sampling of the fish community was conducted at three sites in Big Bayou Creek, one site in Little Bayou Creek, and at one off-site reference station (Massac Creek) during March and September 1994. Qualitative sampling at one site in Little Bayou Creek was conducted during March 1994. Data on the fish communities of Big Bayou Creek and Little Bayou Creek downstream of the plant were compared to data from reference sites located on Big Bayou Creek above the plant and on Massac Creek. These comparisons indicated a slight but noticeable degradation in the communities downstream of the site. 


\section{COMPARISON OF DOSE LEVELS}

The dose received by a given individual can vary widely from year to year depending on numerous factors. The average individual in the United States receives a dose from natural exposure that is more than 200 times higher than he or she receives from nuclear industry operations (see Figure 16).

The average dose caused by background radiation also varies widely. In the United States, the average is about 300 mrem per year; however, some people in other parts of the world receive a dose more than four times this amount. For example, in some areas of Brazil the dose to inhabitants can be more than 2000 mrem per year from background radiation. These variations are caused by several factors, most notably the type and amount of naturally occurring radionuclides in the soil (see Figure 17). This diversity in background radiation, not human-made radiation, is responsible for the large differences in the dose to average individuals. Because people living in areas with high levels of background radiation do so without proven harm, it is assumed by most in the scientific community that the extremely small variations in dose caused by Paducah releases have inconsequential, if any, effect on humans. See Figure 18 for a comparison of dose levels from various sources.
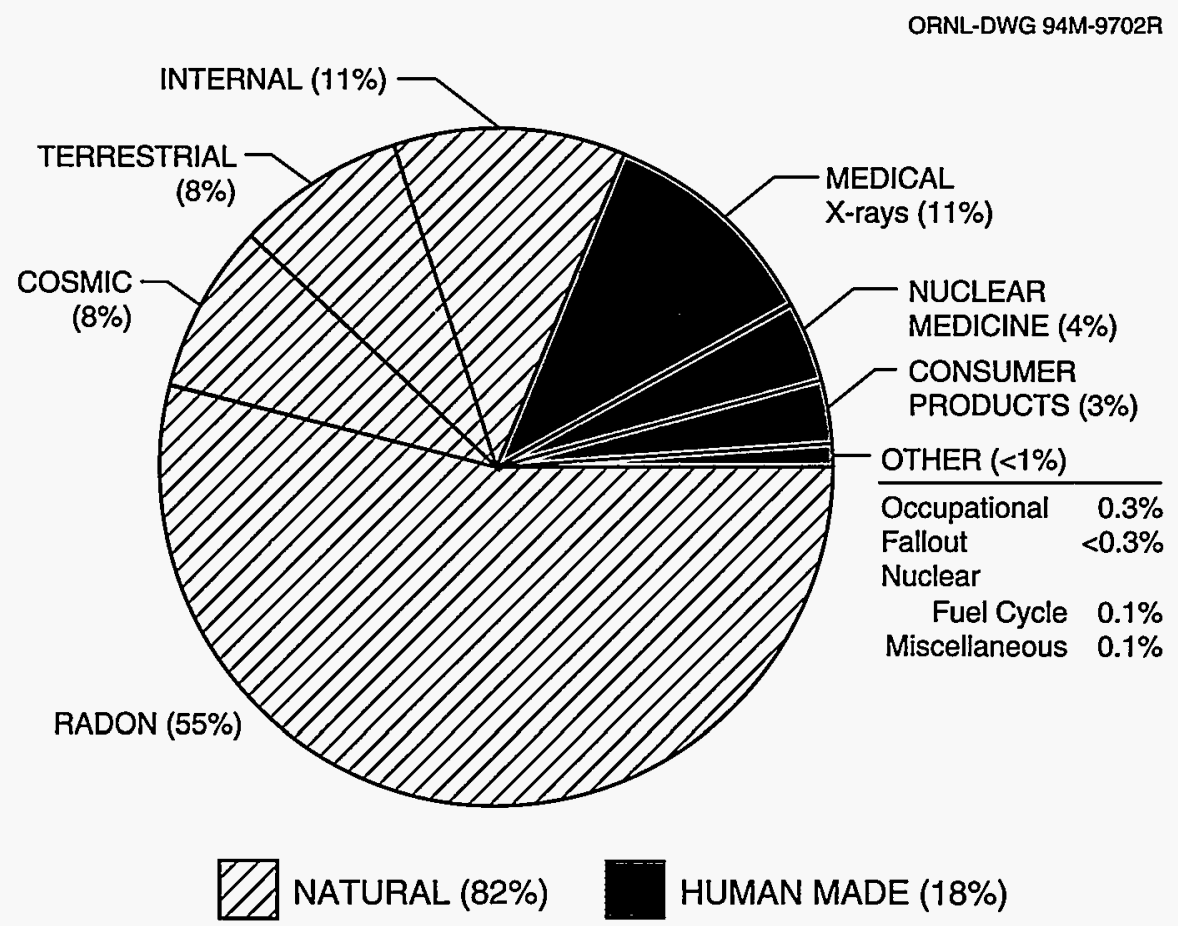

Figure 16. Source of radiation. Radiation has always been present, and every person who has ever lived has been exposed. Although modern technology seems to have greatly increased the exposure rate, this is not necessarily the case. Exposure to human-made radiation varies greatly based on a given individual's product choices and medical treatments. In fact, exposure varies more based on where a person lives than on exposure to human-made sources. For example, the average individual in the United States receives 28 mrem per year from radioactive elements in the soil. However, the average dose from the soil in some areas of France is 350 mrem per year. (Figure redrawn with permission from the National Council on Radiation Protection and Measurements, Ionizing Radiation Exposure of the Population of the United States, NCRP Report No. 93, 1987.) 


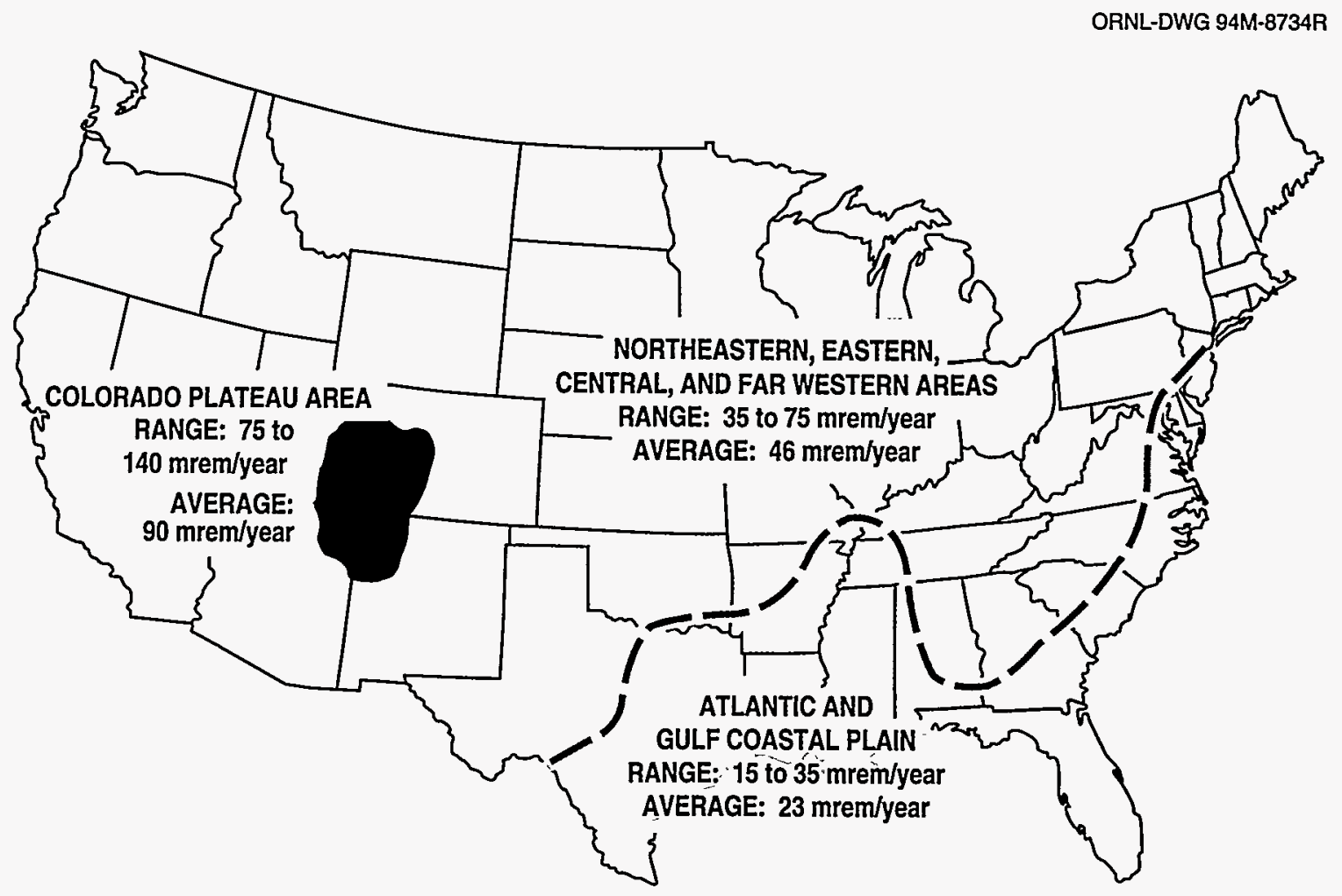

Figure 17. Average dose from terrestrial radiation in the United States. Large deposits of uranium and thorium ores in the southwest are responsible for the higher-than-average dose in the area known as the Colorado Plateau. (Figure redrawn with permission from the Subcommittee on Risks of Low-Level lonizing Radiation, Low-Level Radiation Effects; A Fact Book, The Society of Nuclear Medicine, Inc., 1985.)

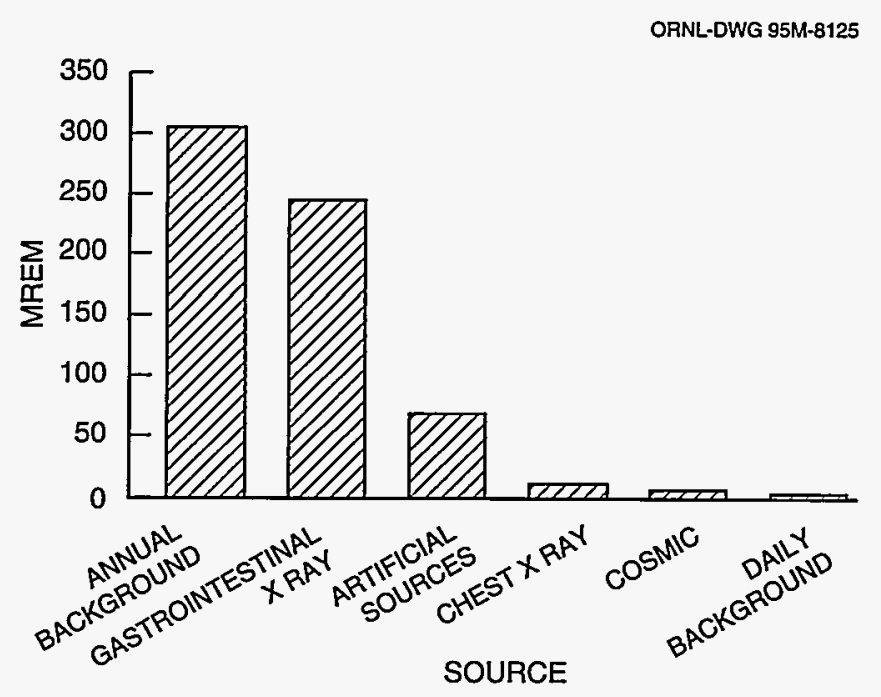

Figure 18. Comparison of dose from various radiation sources. 


\section{SO ... WHAT DOES IT ALL MEAN?}

Everyone who works at the Paducah site remains committed to working safely, with regard to each other, the public, and the environment. This goal will be accomplished by keeping emissions as low as reasonably achievable, enhancing the strict safety controls that are already in place and by using state-of-the-art technology to complete environmental remediation projects in the most cost-effective and efficient manner possible. 